\title{
Whatever Happened to Labourism?
}

\author{
James Naylor, Brandon University
}

Craig Heron's 1984 Labour/Le Travail article on labourism played an important role in bringing the focus of the "new" (as it was at the time) labour history out of the nineteenth century. ${ }^{1}$ Historians such as Gregory Kealey and Bryan Palmer had built upon British and American historiographical precedents exploring the nexus of class culture and political activity through the period of initial industrialization. ${ }^{2}$ Yet the subsequent flowering of working-class political activity, particularly in the wake of Canada's Second Industrial Revolution at the beginning of the twentieth century — so well explicated by Heron in a separate study — had received surprisingly little attention. ${ }^{3}$ By World War I, although "labourism" had become a significant presence in working-class communities across Canada, it remained, as Heron rightfully remarked, the "neglected child of the Canadian left." In part, the "diffuse, unsystematic" ideology of these emerging "Independent Labour" parties, as well as their limited electoral success before the war, had never attracted very much academic attention. ${ }^{5}$ After World War I, labourists ran and increasingly won office at all levels of government. But their story had been eclipsed, in large part, by the more dramatic events of explosive moments such as the Winnipeg General Strike. In Ontario's urban centres - a story I was drawn to at the same time Heron was publishing his analysis of labourism-labourists were remarkably successful and joined the organized farmers in governing the province. ${ }^{6}$ The floodgates seemed to be opening. However, the movement promised much, but delivered littlespelling, it seemed, the death of labourism. It seemed to disappear, but is that the end of the story?

In Heron's article, labourism clearly had a "best before" date. Securely rooted in communities of craftworkers, with their cultures of workplace self-respect and craft pride and with ideological debts to nineteenth-century radicalism and Gladstonian liberalism, labourism reflected such workers' desires for inclusion in a more politically egalitarian social order. They did not directly challenge the Lockean notion that political citizenship was rooted in property ownership but, along with other "producerist" ideologies, saw value in their hard-won skills and useful labour. But modern capitalism devalued their skills — their property — and denied them the full fruits of democracy. This was a losing battle. Heron's tale of the demise of labourism is both sociological and political. On one hand, labourism would share the fate of the independent craftsman; by the early 1920s, Heron notes, "technological and managerial innovations had ... transformed craft jobs or pushed craftsworkers to the margins of the work world."7 Just as significantly, the political inadequacies_-indeed naiveté_-of labourism were displayed in their inability to 
capitalize on electoral triumphs in the aftermath of World War I. Parties such as the Independent Labour Party (ILP) in Ontario certainly brought workers to the table of political power, but they could not point to many material achievements that they were able to bring home. The ILP had no clear notion of what they wanted from the provincial state, particularly in the face of economic depression and corporate intransigence. Even if they had a clear plan, they lacked sufficient weight in, or out, of the provincial parliament, to push their farmer allies to support labour's cause. Labourism was increasingly displaced by a more explicitly anti-capitalist politics which would, in stages, find homes in the Communist Party (CP) and the Cooperative Commonwealth Federation (CCF).

This is what I also argue in The Fate of Labour Socialism. ${ }^{8}$ CCF historiography, I suggest, has erred by minimizing the central role that workers played in its initial organization, tending to focus instead on League for Social Reconstruction (LSR) intellectuals, social gospel ministers, and farmers. ${ }^{9}$ Labour was at the core of the initial movement leading to the creation of the CCF, not only at the 1932 Western Labour Conference in Calgary, where Socialist and Labour Parties from across the West created the CCF, but also in Ontario where the new Socialist Party and more broadly representative Labour Conference spearheaded a parallel movement. But these workers-labour socialists as I call them-were in many ways often quite different than those who had fueled labourism. The experiences of 1919, the labourist debacle (particularly in Ontario), the repression that followed the revolt, and then the onset of the Great Depression had created more radicalized labour networks whose primary goal was - one way or another - to replace capitalism with socialism. This led to a substantial discontinuity with an earlier labourism. The few places where labourism seemed to survive, as in Humphrey Mitchell's Central Hamilton ILP, or perhaps Tom Uphill's Fernie, BC, were vanishing anomalies. ${ }^{10} \mathrm{I}$ argued that those who, implicitly or explicitly, saw a continuity in what they tended to identify as the gradualist politics of ILPs and the CCF were mistaken; at least they were misreading or misunderstanding what CCFers felt they were doing.

However, there have been clear reasons for historians' misconception of the CCF. In some contexts, CCFers sometimes appeared to be doing pretty much the same as labourites had in the past, and sometimes explaining their activity in very similar terms. From Martin Robin, in his 1968 book about labour politics, to Stephan Epp-Koop's 2016 study of Winnipeg's political left in the two decades after the General Strike, observers have tended to describe the very limited political vision of post-World War I non-Communist labour politicians in terms that would apply to an earlier labourism. ${ }^{11}$ Indeed, post-World War I labour parties and, after 1932, the CCF, present a sort of lenticular image (those pictures where the image changes depending on the viewing angle). Viewing the CCF from one perspective, we see socialists dedicated to systemic transformation which they tended to label revolutionary; seen from another, we see a narrow defense of workers' representation within liberal democracy. 
The CCF, of course, was a house with several rooms, and many of its inhabitants had a complex relationship with the Federation's socialism. The LSR's immediate roots were in the progressive wing of Liberalism, a place where many farmers - participants in the Progressive movement of the previous decade-also felt most comfortable. Some early farmer adherents to the CCF were overtly wary of socialism; the United Farmers of Ontario voted with their feet and left the CCF. ${ }^{12}$ In contrast, the labour socialists of English Canada's major urban centres represented the CCF's socialist backbone.

Ironically, though, the traditionally labourist image was simultaneously apparent in these cities. Winnipeg, where the local ILP was both active and electorally successful in city politics, is a case in point. The Manitoba (actually, largely Winnipeg) ILP participated in the founding of the CCF, retaining the ILP name even after affiliating. The organization had been founded after the Winnipeg General Strike, and represented the shift to a clearer socialist politics. Its weekly newspaper spoke a language of socialism explaining that Gladstonian liberalism no longer existed. ${ }^{13}$ The struggle was to challenge ruling class control of the laws, the courts, and the military (in short, the state). ${ }^{14}$ Manitoba's ILP distanced itself from what it derided as reformism, particularly of the sort associated with the British Labour Party. Their paper declared: join the ILP if you are not "afraid your piano or car might be scratched in the change from capitalism to socialism." 15

But reading the ILP's Weekly News, it was hard to find any damage being done to very many vehicles or furniture. Instead a byline "As the Clock Turns" details the much less dramatic minutiae of the workings of Winnipeg City Council from the ILP's point of view. The ILP's municipal program differed little from its prewar labourite forebears: fair wages and improved working conditions for city employees, civic services for workers, and free textbooks for students topped the lists. ${ }^{16}$ Indeed, the ILP's biggest campaigns were for the democratization of municipal government by removing property qualifications and the long struggle against the privately-owned street railway monopoly; very little distinguished this program from that of labourists a decade or two before. ${ }^{17}$ The Winnipeg ILP's reputationor at least the way in which it has been remembered - stemmed from the centrality of municipal political activity to its very being. The ILP's broader socialist message was largely absent in this venue. Indeed, despite the deep waters of working-class activity and education in which it swam, Manitoba CCF Provincial Secretary, Beatrice Brigden painted the Winnipeg ILP as little more than a machine to elect civic politicians. ${ }^{18}$

While Winnipeg is the best example, a broader point can be made. Assessments of the success of the CCF in electoral terms tend to measure it in terms of seats in federal and provincial legislatures. But, the most notable successes in the 1930s came from elsewhere. David Lewis told the 1938 National Convention that the CCF had 1,200 elected municipal officials. ${ }^{19}$ This seems incredible, and is difficult to verify, both for the obvious reason of the size of the job required to check 
local sources across the country, and also because of the added problem of the often-questionable status of partisan politics in municipal races-particularly, but not entirely, in smaller locales. Party labels were often avoided. Urban historian John H. Taylor noted the electoral successes and, for the most part, the ineffectiveness during the 1930s of both "maverick" mayors relying on their populist charisma, and of socialists, as the credibility of the "conventional" sources of civic political leadership_-small business and the professions_-was eroded by the economic crisis. $^{20}$

During the 1930 s and early 1940 s, labour party or CCF members were elected mayor in Toronto, Windsor, Winnipeg, Regina, Edmonton, Calgary, and Vancouver. Not surprisingly, they were often among the CCF's best known figures: long-time socialist James Simpson in Toronto in 1935; General Strike notable John Queen in Winnipeg (jailed after the Winnipeg General Strike and mayor for most of the period from 1935 to 1942) and former BC CCF President and popular CCF radio propagandist Lyle Telford in Vancouver in 1939. These were a mixed bunch, with varied but generally real socialist credentials. Queen was a speaker at the famed Walker Theatre meeting in 1919 where he led the cheer for the Russian Revolution, and Telford - albeit a man of varying opinions who often created a stir in the CCF_-viewed Communists and the CCF as having the same end in mind. ${ }^{21}$ The two parties differed, perhaps, on how to transform society, but shared a vision of a world of freedom without scarcity or exploitation. Telford quit the CCF to run for mayor of Vancouver. This probably reflected the status of party politics municipally and Telford's own wishes to not be, or to not be seen to be, beholden to the CCF, but his political history was known to all. ${ }^{22}$ Smaller centres also saw significant socialist leadership: W.A. (Bill) Pritchard, pre-World War I Socialist Party of Canada stalwart and subsequent One Big Union advocate, who was also imprisoned in the wake of the Winnipeg General Strike, was elected reeve of Burnaby, British Columbia, in 1930.

The resulting municipal gains for labour were limited. To some extent, this was because mayors largely depended on the balance of power on city councils. Rarely did they find themselves, as John Queen did for a single year, with a majority of sympathetic aldermen (if the Communists are counted-as they effectively were). There were some significant positive outcomes: Queen, with a labour-dominated council, was able to increase relief rations by ten per cent and otherwise "humanize" the system. ${ }^{23}$ James Simpson received praise for refusing to cut civic workers' wages and for never unleashing the police on demonstrators during his term in office. ${ }^{24}$ (Edmonton's Dan Knott could hardly make the same claim. ${ }^{25}$ ) But these were pro-labour measures entirely consistent with labourite values. And, as Erik Strikwerda pointed out in his comparative study of relief regimes across the prairies, the improvements brought by municipal labour, or CCF governments, were only different from conventional civic leaders in "degree rather than form." 26 Take, for instance, the case of Bill Pritchard: Peter Campbell describes his period in mu- 
nicipal government as a curious and temporary episode, perhaps spurred by personal issues, in which Pritchard took a "Fabian turn" away from the "doctrinaires" in the emerging $\mathrm{CCF}^{27}$ The evidence of this is that he effectively limited his program to issues of unemployment and relief at the expense of broader questions (although he did condemn capitalism as the source of the crisis). But these narrower issues reflected the limits of his powers in the civic field; even here, Pritchard strained at the boundaries, defying provincial and federal regulations that prohibited providing relief to strikers, and "misappropriating" municipal funds to redirect them towards the costs of relief. ${ }^{28}$

The reasons for socialists' limited vision was perhaps best explained by the Socialist Party of Canada (SPC) wing of the BC CCF, an organization given to openly reflecting upon and explaining its actions. Already in 1931, the BC ILP (which was shortly to change its name to the SPC), basically apologized for running in the upcoming civic elections, explaining that "in putting forward our candidates for municipal offices we realize the limitations of these offices and do not wish to convey the impression that we think we can revolutionize economic conditions through municipal activity." ${ }^{29}$ The BC SPC, in fact, was generally quite circumspect in limiting expectations that could arise from a CCF victory at any level, pointing out that, in the short term, all they would be able to do was administer capitalism. This was even more the case at the level of municipal governments which, in Canada, had limited powers delegated to them by provincial legislation. This led the BC SPC, in 1932, to debate the point of participating in civic politics at all. Besides using it as an occasion to further socialist education, they concluded, their goal should be to "support measures which increase workers' standard of living and return to workers a greater percentage of values they have produced." ${ }^{30}$ Although reworked in Marxist language, they were articulating the aim of supporting workers' livelihoods; again, hardly remote from labourist concerns. In 1936, the BC CCF was still explaining why it ran civically; on this occasion, they explained that it provided experience in governing. In short, it was a training school for "real" governmental responsibility at the provincial and especially federal level. ${ }^{31}$ Labour rights (converting municipal day labour to full-time jobs) and democratic and educational improvements (such as supporting the expansion of libraries) were central issues: again, largely consistent with labourism. ${ }^{32}$ The following year, still feeling the need to defend their civic participation and its apparently narrow scope, they sought to defend themselves by explaining that the CCF's role in civic government was not to shore up the system. Given perhaps the challenges of administering the relief system without being able to implement any alternatives, the CCF felt compelled to explain that "the socialist movement does not go to the trouble of electing representatives to civic office for the prime purpose of assisting in the administration of the capitalist system." ${ }^{33}$ Rather, it was to make life somehow better for the masses - in its vagueness, it matched the labourism of earlier years.

Problematically for the BC CCF, the party's place in municipal politics was 
called into question when Lyle Telford decided to run for mayor of Vancouver as an independent. In explanation, he cited the general absence of partisan politics in city government. The desire to keep organized partisanship out of civic politics had a long and unclear history, but was certainly connected to the rhetoric of providing business-like government. By the twentieth century it received an added boost as an ideological means of rejecting organized challenges to conventional politicians. ${ }^{34}$ In Telford's case, he adopted the policy because he no doubt did not wish to have his hands tied by the CCF-he had a tendency to run afoul of some other prominent CCFers. In the end, Telford quit the CCF; the party's conclusion, at least publicly, was that the CCF connection had made little difference. ${ }^{35}$ It certainly would reinforce the notion that the CCF had little to say, as a party, in the civic field. Telford's rejection of partisanship was far from unique in the CCF. In Windsor, in 1935, ten CCFers ran as independents in the civic election, including the successful mayor. ${ }^{36}$ Many were unhappy about this but, not surprisingly, a motion at the Ontario CCF provincial convention to ban CCFers from running as independents was defeated. ${ }^{37}$

It soon became apparent that there was more to the Windsor story than the CCF press was letting on, and events there, and in the same period of time in several other Canadian cities, demonstrate the tenacity of what we could interpret as "labourism" — or at least the persistence of a minimal program of defending liberal democracy and workers' living standards_ — at the municipal level. The Windsor election was but one of a series of municipal popular fronts that emerged across the country. The Communist Party became, in the mid-1930s, something of a force in civic politics and one that, for several reasons, the CCF found it impossible to ignore. The character of the Communists' participation was shaped by their international goal of building a broad alliance — a popular front - in the face of the rise of fascism. In effect, this meant focusing on the maintenance of democratic rights and workers' livelihoods. It is not difficult to see how such a set of policies could easily align with the CCF's "labourist" face in municipal politics.

The most successful of these civic popular fronts - and most prominent since the national CCF leadership did publicize the experience after it collapsedwas in Regina. There, the Civic Labour League, uniting the CCF and the Communist Party, was established in the aftermath of the On-to-Ottawa Trek and won control of City Council in the 1935 election. As was generally the case in the 1930s, municipal politics revolved around relief issues and the labour-led council was able to make some improvements, most importantly replacing the voucher system with cash payments. It should be noted, though, that the "conventional" City Council in Saskatoon had already accomplished this. In general, hopes of further advances in public works - particularly in the pressing area of housing-were stymied by the lack of support by senior governments. ${ }^{38}$

The confusing world of Toronto labour politics provides further insight into the character of municipal politics. While attempts by the Communists to lure 
the CCF into electoral alliances fell flat in provincial and federal contests in Ontario, municipal politics was quite another matter. For one thing, the ethnic and class configuration of the city, along with Communist strength in some sectors of the labour movement, and the fact that their votes were concentrated due to the civic ward system, meant that the Communist Party was a strong and persistent electoral force, particularly in the garment district. ${ }^{39}$ Stewart Smith was elected to Toronto City Council in 1936, and was joined by Joe Salsberg the following year. The presence of such prominent Communists on Council demonstrated that this was a world where the CCF, clearly, could claim no monopoly of labour politics. How to respond to this created a storm in the CCF, as a significant schism developed in 1937 over whether or not to run a CCF candidate against Salsberg. David Lewis urged the CCF candidate to withdraw, for which he was soundly rebuked by J.S. Woodsworth. Lewis responded, pointing out that not only was Salsberg a well-respected labour figure: he also had, through the recently created Labour Representation Association (LRA), the support of the Toronto District Labour Council. ${ }^{40}$ The Ontario CCF's Industrial Relations Committee, in which dozens of trade unionists took part, along with the Provincial Executive of the party, debated the issue of participating in the LRA at length, and to no clear conclusion. ${ }^{41}$ In many ways, the CCF was over a barrel as Ontario unions, even outside Toronto, debated endorsing the popular-frontist LRAs that emerged in several centres. ${ }^{42}$

As Lewis subsequently explained to Woodsworth, the LRAs had support from many beyond the Communist Party, including the Toronto Independent Labour Party with which it was affiliated. But based on its roots in the city's labour movement, and particularly the trades and labour council, the LRA had secured a certain degree of autonomy from the CCF. This was reflected in the refusal of the provincial CCF, and the willingness of the Toronto ILP, to affiliate with the LRA. The latter demonstrated the importance of the fullest possible trade union unity at the polls. ${ }^{43}$ As Lewis eventually noted, "a good many of our own good people" in the CCF "are drawn" to the LRAs. This was, he added, most pronounced at the municipal level where "it is extremely difficult in most Canadian cities to insist on party label in municipal elections." ${ }^{\prime 4}$ The issue continued to be more one of working-class representation than of a specific political program. This was reinforced by the resolutely non-radical character of the Communists' participation in civic politics, in keeping with its popular front policy. As with labourism, issues key to the material lives of their working-class constituents dominated. This meant activism: support for those on relief, the defense of workers fighting for workplace improvements, particularly if they worked for the city, and social improvements to the city which would benefit workers. As labourites had been in the past-perhaps even more so-Communists were vociferous in their defense of workers, were committed to community-level representation, and were uncompromising in their demand for equal rights for working-class citizens. But as this implies, they did so by defending working-class citizenship within the existing social order. As the Toronto 
Star remembers, in response to a redbaiting accusation that he was a pawn of Moscow, Salsberg quipped, 'You're right. I got a telegram from Joe Stalin this morning ordering me to ask for a park for Ward 4." ${ }^{45}$

Municipal popular fronts did not appear everywhere, of course, but even where they did not the effect was in many ways similar. In Winnipeg, where relations between the CCF-affiliated ILP and the Communists are generally considered most difficult, ILP and CP aldermen generally found themselves, not surprisingly, allied on civic issues - issues that generally revolved around just those kinds of issues that spoke to the material well-being of city's workers who had voted them into office. While the CP may have been more strategic in focusing on such of issues, as opposed to contemplating what a socialist city might look like, ILPers and CCFers acted in much the same way, not considering the possibilities of any kind of broader social or political experimentation. Certainly, the CP's strategy only reinforced the ILP/CCF inclinations to constrain themselves to what might seem to be important issues but were, in the end, often parochial.

For a variety of reasons, then, "socialism in one city" was on nobody's agenda, regardless of the electoral breakthroughs the left made on occasion. The continuity with ideological constraints associated with an earlier labourism can be explained by a number of factors including a fixation on the national state monopolizing the necessary political authority to transform society, the very limited powers of municipal governments, and a limited imagination regarding the potential of mobilizing local populations around broader political goals. There were, as well, some continuities within the labour movement that tied them to their labourist past. Perhaps most importantly, city-wide trades and labour councils remained the main forum of trade unionists' political debate. By contrast, such federated provincial and federal labour bodies were either nonexistent, or quite skeletal. Local trades and labour councils met regularly and naturally addressed unionists' concerns within a particular urban jurisdiction: fair wages, the civic franchise which discriminated against working-class citizens, the abuses of privately-owned street railway systems, and the like. This had changed little over the decades, and such trades councils had a direct line to their locally elected CCF or labour party aldermen. It is worth adding that the achievement of women's suffrage changed this pattern very little. The gendered character of 1930 s unions meant that few women achieved status in the labour movement that could be transferred to the electoral arena. Notably, one woman who did so, Vancouver's Helena Gutteridge-in spite of her long and prominent record in women's causes_-primarily identified herself not as a feminist but as "a trade union woman"; her route to City Council had led through the Vancouver Trades and Labour Council. ${ }^{46}$ To the extent they were electorally active at the city level, labour and CCF women had a greater impact on local school boards where their political programs reflected a heady mix of maternalism and socialism, fighting for issues of public health in schools, opposition to cadet training, and a range of curricular changes. ${ }^{47}$ By contrast, city councils appeared stuck in a labourist 
past as socialists, of whatever stripe, tended to fight for an agenda not unlike that laid out by labourists some decades before: defending the class interest of their constituents, but not redefining it in the ways the left did at a national level.

Labourism, then, had a peculiar afterlife, outliving the world of the independent craftworkers who had created and nourished it and, ironically, kept alive by Communists and CCFers who envisaged a future that was at odds with labourism's much more limited goals. But labourism, too, had been a mutation of Victorian-era radicalism that early twentieth-century workers had reshaped to conform to their own evolving understanding of class, power, and democracy. Heron's careful explication of the sources and character of labourism provides a model of historical analysis which is particularly useful in understanding working-class political movements. Labourism, as Heron implies, could easily be consigned to vaguer and somewhat timeless categories of reformism, liberalism, or social democracy. It was, though, a dynamic, popular, and specific movement that, by reflecting the history, values, and interests of a significant sector of early twentieth-century workers, spurred many to political action. And, like any deeply-rooted set of beliefs, its echoes reverberated even as its shortcomings became apparent. New generations of workers, increasingly distant from Heron's craftworkers, would have to reimagine working-class politics. Labourism was a resource available to them-one that could be reworked, used, or abandoned, as they found fit.

\section{NOTES}

${ }^{1}$ Craig Heron, "Labourism and the Canadian Working Class," Labour/Le Travail 13 (Spring 1984): 45-76.

${ }^{2}$ Gregory S. Kealey, Toronto Workers Respond to Industrial Capitalism, 1867-1992 (Toronto: University of Toronto Press, 1980); Bryan D. Palmer, A Culture in Conflict: Skilled Workers and Industrial Capitalism in Hamilton, Ontario, 1860-1914 (Montréal and Kingston: McGill-Queen's University Press, 1979); Gregory S. Kealey and Bryan D. Palmer, Dreaming of What Might Be: The Knights of Labor in Ontario (Toronto: New Hogtown Press, 1987).

${ }^{3}$ Craig Heron "The Second Industrial Revolution in Canada, 1890-1930," in Class, Community, and the Labour Movement: Wales and Canada, 1890-1930, eds. Deian Hopkin and Gregory S. Kealey (Aberystwyth: Llafur/Committee on Canadian Labour History, 1989), 48-66.

${ }^{4}$ Heron, "Labourism and the Canadian Working Class," 45.

${ }^{5}$ Ibid., 72. 
${ }^{6}$ James Naylor, The New Democracy: Challenging the Social Order in Industrial Ontario 1914-25 (Toronto: University of Toronto Press, 1991).

${ }^{7}$ Heron, "Labourism," 70. Much of this emerged from the labour process literature sparked by Harry Braverman, Labour and Monopoly Capital (New York: Monthly Review Press, 1974).

${ }^{8}$ James Naylor, The Fate of Labour Socialism: The Co-operative Commonwealth Federation and the Dream of a Working Class Future (Toronto: University of Toronto Press, 2016).

${ }^{9}$ Michiel Horn, The League for Social Reconstruction: Intellectual Origins of the Democratic Left in Canada 1930-1942 (Toronto: University of Toronto Press, 1980); Kenneth McNaught, A Prophet in Politics: A Biography of J.S. Woodsworth (Toronto: University of Toronto, 1959); S.M. Lipset, Agrarian Socialism: The Cooperative Commonwealth Federation in Saskatchewan, A Study in Political Sociology (Berkeley: University of California Press, 1950).

${ }^{10}$ Craig Heron, Lunch-Bucket Lives: Remaking the Workers' City (Toronto: Between the Lines, 2015), 539-542; A product of Welsh coalmines, journalist Bruce Hutchison opined in 1932 that Uphill "is not a pink Socialist even. He is simply a working man, out to help the underdog." Quoted in Robert McDonald, "Simply a Working Man': Tom Uphill of Fernie," in A World Apart: The Crowsnest Communities of Alberta and British Columbia, eds. Wayne Norton and Tom Langford (Kamloops: Plateau Press, 2002), 106. McDonald concurs with that assessment, adding that the vision of his ideal society was rooted in mid-Victorian Radicalism.

${ }^{11}$ Martin Robin, Radical Politics and Canadian Labour, 1880-1930 (Kingston: Industrial Relations Centre, Queen's University, 1968); Stefan Epp-Koop, We're Going to Run this City: Winnipeg's Political Left after the General Strike (Winnipeg: University of Manitoba Press, 2016).

${ }^{12}$ Naylor, The Fate of Labour Socialism, 66-111.

${ }^{13}$ Marcus Hyman, Weekly News (Winnipeg), October 16, 1925.

14 "Don't Scab at the Ballot Box," Weekly News (Winnipeg), October 23, 1925.

15 “Are You for Labor?” (editorial), Weekly News (Winnipeg), June 7, 1929.

16 “I.L.P. Municipal Platform, 1929,” Weekly News (Winnipeg), November 8, 1929.

${ }^{17}$ Epp-Koop, We're Going to Run this City, 41-46, 130-131.

${ }^{18}$ Naylor, The Fate of Labour Socialism, 171.

19 "Confidence and Unity Mark CCF Convention," New Commonwealth (Toronto), August 6, 1938.

${ }^{20}$ John H. Taylor, "Mayors á la Mancha: An Aspect of Depression Leadership in Canadian Cities," Urban History Review 9, no. 3 (February 1981): 3-14.

21 "Prejudices or Sympathies" (editorial), BC Commonwealth, May 10, 1935.

${ }^{22}$ University of British Columbia Special Collections (UBC), Angus MacInnis Me- 
morial Collection (AMMC), Box 46, File 46-3 CCF (Provincial Party), minutes, Provincial Executive, CCF (BC), November 14, 1938 and December 15, 1938.

${ }^{23}$ Epp-Koop, We're Going to Run this City, 124.

24 “Simpson Fights Wage Cuts," New Commonwealth (Toronto), March 30, 1935; “The Rule of Law" (editorial), New Commonwealth (Toronto), December 21, 1936.

${ }^{25}$ Alvin Finkel, "The Rise and Fall of the Labour Party in Alberta, 1917-42," Labour/Le Travail 16 (Fall 1985): 86.

${ }^{26}$ Erik Strikwerda, The Wages of Relief: Cities and the Unemployed in Prairie Canada, 19291939 (Edmonton: Athabasca University Press, 2013), 175.

27 Peter Campbell, Canadian Marxists and the Search for a Third Way (Montréal and Kingston: McGill-Queen's University Press, 1999), 110-111.

${ }^{28}$ Ibid., 108.

29 "Municipal Campaign Manifesto," The Challenge (Vancouver), November, 1931.

${ }^{30}$ UBC, AMMC, Box 45A, File 45-3 Socialist Party of Canada, minutes, 1931-33, Provincial Executive, September 12, 1932.

31 “The Civic Election" (editorial), The Federationist (Vancouver), September 11, 1936.

${ }^{32}$ The full municipal election program is in The Federationist (Vancouver), December 3, 1936.

33 "C.C.F. and Civic Affairs," The Federationist, June 24, 1937.

34 Taylor, "Mayors á la Mancha," 4.

35 "Vancouver CCF Mayor Resigns from Party; Will be Independent," Manitoba Commonwealth, January 13, 1939.

${ }^{36}$ Library and Archives Canada (LAC), CCF Records, Volume 49, Ontario Council and Executive Minutes, 1934-1937, Provincial Executive minutes, June 3, 1935, June 26, 1935, and July 12, 1935.

${ }^{37}$ LAC, CCF Records, Volume 48, Ontario Conventions, 1935-1945, Annual Convention, April 25, 1935.

${ }^{38}$ J. William Brennan, "'The common people have spoken with a mighty voice': Regina's Labour City Councils, 1936-1939,' Labour/Le Travail 71 (Spring 2013): 49_ 86.

${ }^{39}$ It was the Communists, more than the CCF, that would dominate working-class representation on Toronto City Council at the end of World War II. Kevin Brushett, "People and Government Travelling Together': Community Organization, Urban Planning and the Politics of Reconstruction in Toronto 1943-1953," Urban History Review 27, no. 2 (March 1999): 48-49.

${ }^{40}$ LAC, CCF Records, Volume 99, David Lewis, 1936-1939, Woodsworth to Lewis, September 27, 1937 and Lewis to Woodsworth, September 29, 1937.

${ }^{41}$ LAC, CCF Records, Volume 49, Ontario Council and Executive minutes, 1934 
1937, "Report Industrial Relations Committee," November 6, 1937 and Ontario Council and Executive Minutes, 1938-1939, CCF Ontario Provincial Executive, October 20, 1938.

${ }^{42}$ LAC, CCF Records, Volume 49, Ontario Council and Executive minutes, 1934 1937, Ontario Provincial Executive, December 22, 1937.

${ }^{43}$ LAC, CCF Papers, Volume 49, Ontario Council and Executive minutes, 1934 1937, Ontario Provincial Executive, August 9, 1937 and September 26, 1937. George Watson, the president of the Toronto District Labour Council, carried this debate publicly, attacking Woodsworth in the press and defending the LRA.

${ }^{44}$ LAC, CCF Papers, Volume 107, J.S. Woodsworth, 1933-1942 (1 of 3), Lewis to Woodsworth, November 29, 1938.

${ }^{45}$ Nicolaas van Rign, “'Godfather of Spadina’: Joe Salsberg One-Time Communist Was Compassionate," Toronto Star, February 9, 1998.

${ }^{46}$ Joan Sangster, Dreams of Equality: Women on the Canadian Left, 1920-1950 (Toronto: McClelland and Stewart, 1989), 119. See also Irene Howard, The Struggle for Social Justice in British Columbia: Helena Gutteridge The Unknown Reformer (Vancouver, University of British Columbia Press, 1992).

${ }^{47}$ See Patricia Roome, "Amelia Turner and Calgary Labour Women, 1919-1935," in Beyond the Vote: Canadian Women and Politics, eds. Linda Kealey and Joan Sangster (Toronto: University of Toronto Press, 1989), 89-117; Peter Campbell, Rose Henderson: A Woman for the People (Montréal and Kingston: McGill-Queen's University Press, 2010). 